\title{
2 \\ International political economy and global social change
}

Political economy is concerned with the historically constituted frameworks or structures within which political and economic activity takes place. It stands back from the apparent fixity of the present to ask how the existing structures came into being and how they may be changing, or how they may be induced to change. In this sense, political economy is critical theory. (Cox, 1995: 32)

$\mathrm{T}$ he field of IPE is inextricably bound up with understandings of global social transformation. Indeed, for many, the revival of IPE in the 1970s precisely coincided with the inability of conventional IR frameworks to 'fully comprehend structural change' (Gill, 1997: 7). IPE, by contrast, claims to offer a distinctive ontology, one that is attuned to social forces and social relations on a global scale, and also a distinctive epistemology that is 'open' to diverse insights on social transformation (Strange, 1984; 1994). ${ }^{1}$ Hence, as Robert Cox has it, IPE embodies inherent critical potential, an ability to 'stand back' from the apparent order of things and to consider 'the ways reality is defined for different peoples in different eras' (Cox, 1995: 35). A significant part of this critical bent is held to lie in the interdisciplinarity that is embraced by 'heterodox' IPE (Amin et al., 1994). The willingness to consider the insights of a range of scholars; the acceptance of a range of subject matter and issues; and the raising of voices previously unheard in IR, combine to present IPE as an effective vantage point from which to view social change. Indeed, the IPE perspectives on globalisation could be said to bring together the analytical insights necessary to look critically at global transformation (Germain, 2000). There is perhaps even a suggestion that IPE has become 'globalisation studies' (Payne, 2000) and that global forces will 'dominate IPE for the foreseeable future' (Tooze, 1997: 213).

Despite a potential 'hijacking' of IPE by concerns with globalisation, in recent years there has emerged a critical agenda that directly seeks to challenge the prevailing globalisation discourse. Scholars have directly called for the 'political' to be central to analysis of globalisation (Amoore et al., 1997; Hay and Marsh, 1999); and for IPE to 'historicise' its studies (Amin and Palan, 1996; Amoore et al., 2000). This chapter focuses on the ways in which the field 
of IPE has grappled with the problematic of global social change. Taking Murphy and Tooze's (1991) categories of 'orthodox' and 'new' IPE as analytical tools, I explore the different ontological and epistemological positions, and the implications for understandings of social change. The 'orthodox' origins of IPE may be aligned with a problem-solving mode of knowledge that seeks to 'manage' change in the GPE. 'New IPE' purports to offer a critical perspective in that it begins from a position of problematising the making and transformation of the GPE, thereby restoring reflexive political agency to global social change. Concurring with the broad spirit of the 'new IPE', this chapter nonetheless raises questions surrounding the extent of heterodoxy and openness that IPE has achieved. I suggest that, in part, IPE has reproduced old dichotomies and hierarchies of issues and subjects. In particular, it continues to represent power as something that is wielded by elite global actors, thus rendering the 'ordinary' realms of work and labour secondary concerns to finance and production. I identify the central elements of an IPE of social practice which, I propose, makes everyday practices such as work visible and amenable to inquiry.

\section{Orthodox perspectives in IPE}

IPE as a field of inquiry, a set of questions and a range of assumptions, is a highly contested discipline (Tooze, 1984). Indeed, it is perhaps misleading to consider IPE to be a discipline at all, given that it is characterised by diverse ontological, epistemological and methodological commitments. As a branch of social science IPE has most commonly been labelled a 'sub-field' of IR. Despite its origins in the apparent inability of IR to deal with a globalising world, IPE has been an inheritor of certain legacies of the IR tradition. In this way it perhaps paradoxically comes to represent both a 'break' with IR conventions and an upholding of embedded IR principles. In the context of post-war American social science, IPE takes on a particular orthodoxy that derives from the IR 'science at the service of big-power management' (Cox, 1996: 57). It is in this historical context, of US scholarship in the early 1970s, that IPE was defined in a particular way, reflecting dominant modes of thought and embodying a particular world view. Thus, Stephen Krasner has it that 'the achievements of international political economy have been generated by an epistemology that conforms with the Western Rationalistic Tradition' (1996: 122). We may consider early 'orthodox' IPE to follow the conventions of rationality and positivist inquiry that were outlined in chapter 1.

Despite IPE's diverse roots in classical political economy, sociology and economic history (these are acknowledged more freely by the so-called 'new' IPE scholars), its relationship to IR is an important one to explore. The IPE orthodoxy reproduces significant elements of the realist/liberal IR synthesis, and in so doing establishes a particular understanding of the dynamics of transformation. Emerging at a time of change in world politics, nonetheless 
much of the emphasis was placed on how this change should be managed, and the prevailing order maintained. Though the emphasis on system maintenance has now been critiqued by a proclaimed 'new' IPE, the orthodoxy continues to exert significant influence on the production of knowledge.

If IPE perspectives were to have a unifying feature, a prime candidate would be the analysis of the interrelationships between the 'political', the 'economic', the 'domestic' and the 'international' realms of social life. However, the fundamental cleavages between IPE schools of thought exist around the matter of how we should conceive of these realms. IPE is thus 'defined more by agreement among scholars about what to study than by agreement about how to study it' (Murphy and Tooze, 1991: 1). So-called orthodox scholars answer the question of the relationship between the economic and political realms in a particular way. Researching at the time of the 1971 collapse of the Bretton Woods System and the 1973 oil crises, scholars were struck by the potential for what they considered to be economic issues to impact upon the fundamental relations between nation-states. In this formulation the 'economic' is conceived as the realm of market interactions characteristic of world trade, held to be separate from the 'political' as the realm of state interactions characteristic of IR. IPE becomes a field of study 'concerned with the political determinants of international economic relations' (Krasner, 1996: 108). The separate and unitary realms of politics and economics are conceived as in a linear relationship of tension: 'The tension between these two fundamentally different ways of ordering human relationships has profoundly shaped the course of modern history and constitutes the crucial problem in the study of political economy' (Gilpin, 1987: 11).

Indeed, as Murphy and Tooze argue, the separation and opposition of the realms of politics and economics was an important part of the raison d'être of orthodox IPE: 'What spurred much of the initial IPE research in the early 1970s was a search for new technical rules and norms that could preserve the division between the political and the economic' (1991: 4). The decline of US hegemony and the challenges that were posed to the liberal international economic order (LIEO) were thus understood to have come about as a result of the interpenetration of the political and the economic. Thus, the decline of US hegemony is variously held to have disrupted the operation of the LIEO (Gilpin, 1987), or to necessitate the construction of political regimes and institutions to take on this role (Keohane, 1984; Krasner, 1983). The emphasis is on the problematic of maintaining the LIEO in the absence of a hegemon, or put another way, on the management of change in the world economy.

Out of the overriding concern to theorise and preserve the dichotomy between politics and economics emerged a focus that has conventionally provided the key terrain of debate in IPE - the relationships between states and markets. Gilpin has it that 'the interaction of the state and the market' represent the 'embodiment of politics and economics in the modern world' and that this 'creates political economy' (1987: 9-11). It is clear that states are 
viewed as the central units of political activity, while markets constitute an opposed economic realm. In effect, the sphere of the market is simply added as a 'variable' to the interactions of states dominant in neo-realist IR theory. These spheres are treated theoretically and normatively as discrete entities the task of political economy being to analyse their 'impacts' on one another. The opposition of state to market is mirrored in the identification of domestic and international realms as separately defined spheres. Hence, the focus of study becomes 'the causes and effects of the world market economy .... and the significance of the world economy for domestic economies' (Gilpin, 1987: 14). We cannot simply assume that this conception of states and markets, and domestic from international, reflects a particular historical moment in the study of IPE. Gilpin entrenches the state-market dichotomy still further fifteen years on:

In this book I define global political economy as the interaction of the market and such powerful actors as states, multinational firms, and international organizations, a more comprehensive definition than in my 1987 book The Political Economy of International Relations, although both take a state-centric approach to the subject. (2001: 17)

It is striking that Gilpin here explicitly opposes 'the market' (conceived as a structure), and the actions of states, and in particular multinational firms (conceived as agents). To what extent is it possible or even desirable to conceive of the market as somehow distinct from multinational firms or international organisations? What are markets without the production structures of MNCs and the frameworks of the WTO and IMF? So, not only does Gilpin separate state from market, but also MNCs and international organisations from markets.

The ontological privileging of states-markets relationships has predisposed the IPE orthodoxy to particular methodological concerns. In identifying the 'agency' and power fundamentally with states, and 'structure' with world markets, the orthodoxy can only conceive of social change as state-led. The study of state actions is considered to be at the heart of IPE, just as it was in traditional IR. Global social change, conceived this way, can only be an 'outcome' of changes in 'relational power' such as the demise of a hegemon (Strange, 1988: 24). The preservation of some notion of stability and order, I would argue, is thus given prominence over the struggles and contests that mark the potential for change and transformation. Gilpin's consideration of the question of globalisation leads him to conclude that states remain the central 'power wielders' in the GPE: 'Economic globalisation is much more limited than many realise, and consequently, its overall impact on the economic role of the state is similarly limited' (2001: 363). This clearly demonstrates that the preservation of discrete realms for politics and economics with 'economic' globalisation and 'economic' roles - allows IPE scholars to avoid contemplation of the political dynamics of global social change. The 
discussion of transformative energies in civil society is effectively closed off, or even considered to be 'outside' the discipline, residing in sociology. For the orthodox writers 'plus ça change, plus c'est la même chose', the more world politics appears to change, the more it remains static. While they can conceive of the structural economic environment for the state as transforming, this can only be a function of state power.

In the orthodox framework the purpose of IPE knowledge is to explain the maintenance and loss of order in an international system of states. The expertise of the scholar, so the orthodoxy has it, must be employed objectively in the study of states and markets as unitary entities. There is an overarching impression that the scholars in the orthodox IPE school position themselves as passive observers of the states and markets that they study. It is this claim to objectivity and rationality that has been central to the objections of scholars who consider themselves to be 'doing' 'new' IPE.

\section{New perspectives in IPE}

The so-called 'new IPE' does not represent a cohesive body of scholarship, or even a clearly defined research agenda. The loose grouping of scholars do, however, share a common dissatisfaction with the ability of early 'orthodox' IPE to critically address the dynamics of global social transformation. Thus, Andrew Gamble noted that 'changes in the ideological, political and economic parameters of the world system have created the possibility of a new political economy' (1995: 516). For Palan, 'critical international or global political economy changes the order of the question; it asks how order and change came about' (2000: 17). While the new IPE scholars take different issues and subjects to be the focus of their research, employing a range of theories and methods, they concur that traditional IR and orthodox IPE are epistemologically and ontologically ill-equipped to deal with contemporary global social change. From this standpoint the essence of a 'new IPE' lies in a reaction against the positivist epistemology and ontological separation of the 'political' and 'economic' that is characteristic of the orthodox IPE paradigms.

There have been a number of statements of the 'essence' of the new IPE agenda (Murphy and Tooze, 1991; Amin et al., 1994), and certainly no reading of this terrain would be complete without consideration of Murphy and Tooze's thought provoking 'four steps beyond the orthodoxy' (1991: 26). However, for our purposes it is useful to summarise the central claims of the new IPE scholars.

First, the new IPE seeks to challenge the ontological centrality of the state and interstate relationships that has dominated much of IR and IPE inquiry. This challenge is brought through an ontological commitment to the study of society and social relations. Thus, for Strange IPE: 'Concerns the social, political and economic arrangements affecting the global systems of production, exchange and distribution and the mix of values reflected therein' (1988: 
18). The focus of IPE inquiry becomes 'the basic values which human beings seek to provide through social organisation' (1988). In this way the duality of states-markets and politics-economics is challenged through an understanding of these categories as ways of organising human society or, indeed, ways of thinking about social organisation. The claims to objectivity and rationality made by orthodox scholars are also challenged by a belief in the intersubjective making of reality' (Cox, 1995: 34), thus rendering it neither possible nor desirable that we separate the categories that bring to IPE inquiry from the experiences we have of living in the GPE. This brings me to the second central claim made by the new IPE scholars - that knowledge is historically 'made' in the context of social power relations.

For orthodox IPE scholars, as I have argued, it is important that IPE generates reliable and scientific knowledge that is 'testable against external evidence' (Krasner, 1996: 108). The new IPE rejects this positivist epistemology in favour of a historicism that embodies 'a willingness to investigate and try to explain the contingent historical social construction of agents or actors, which, at other times, may be treated as axiomatic in explanations in terms of rational choice' (Murphy and Tooze, 1991: 28). The focus of IPE questions thus shifts from the explanation of the rise and demise of particular states, to a historically sensitive understanding of why particular agents and structures may be represented as such. Robert Cox's oft-cited 'theory is always for someone and for some purpose' (1996: 87), and Susan Strange's compelling call that we ask 'Cui bono?, Who benefits?' (1988: 117), lead us to consider that orthodox IPE has tended to produce knowledge for certain purposes and for the benefit of particular groups. The new IPE, by contrast, claims to reflect critically on the production of knowledge about the world and on their role in that production. In a world described as globalising, new and critical IPE scholars would need also, then, to reflect on their own relationships to, and experiences of globalisation (see MacLean, 2000).

The third broad claim made by the new IPE scholars is that their IPE is a more inclusive and 'open' field of inquiry. Founded upon a rejection of the privileging of issues of trade and security by the orthodoxy, the claim is that a new IPE is better equipped to explore issues of, for example, technology, finance, production, knowledge, and geography (Amin et al., 1994). Though it is clear that the new IPE agenda of study has not wholly rejected conventional issue hierarchies (Denemark and O'Brien, 1997), there is at least an overt awareness that issues of poverty, struggle and inequality are relatively invisible and need attention (Tooze and Murphy, 1996). Related to this third claim concerning the issue agenda of IPE study, is a fourth claim that raises the question of the theoretical and conceptual 'toolbox' of IPE. Across the various contributions to a proclaimed new IPE there is a unifying thread of 'openness' - or, at least, a professed openness to diverse understandings and competing explanations: 
One small corner of social science is still open and unenclosed ... International political economy is still unfenced, still open to all comers. It ought, we believe, to remain so' (Strange, 1984: ix)

Those who practice a new IPE share a culture of openness to different theories and empirical referents. (Murphy and Tooze, 1991: 30)

In each instance the unifying theme is 'openness' and the idea that IPE should provide a vantage point for an interdisciplinary and heterodox set of understandings. Out of a problematising of the orthodox tendency to dichotomise realms of social life for study, emerges the acknowledgement of the contested nature of IPE knowledge and an 'open' attitude to the structures and agents of social change.

The final claim identifiable in the new IPE literature is precisely its potential to place social change at the heart of inquiry. Against the backdrop of an IPE orthodoxy that explains change in the actions of sovereign states in the context of international economic relations, the new IPE holds that social change is perennial, contingent and dialectical in nature. While for orthodox IPE scholars the purpose of IPE is to bring stability and maintain order, for the scholars of a new IPE the task is to reveal and explore the contradictions, conflicts and tensions that bring about social transformation (Cox, 1995; Gill, 1997; Scholte, 2000). Viewed in this way social change potentially becomes characterised by contestation among agents, and understandings of such contests may open up spaces for alternative structures and practices.

Of course, to identify the claims of the new IPE scholars is not to say that the potential represented by each claim has been fulfilled. Is the new IPE successful in breaking open the linear relationship between politics and economics conceived in orthodox IPE? How 'open' is the new IPE to diverse issue areas and heterodox voices? Does it simply replace 'old' orthodoxies with a new hierarchy of issues and questions? And what light do the different strands of the new IPE shed upon the dynamics of contemporary global social change? Having distilled the essence of a new IPE to its key elements, I will now go on to explore three specific contributions to what we might term new IPE scholarship: the work of Susan Strange, the use of Karl Polanyi's 'double movement' by IPE scholars and the use of Antonio Gramsci's insights in IPE. There are two caveats to be made here. First, these contributions do not in any sense represent the full gamut of contributions to the new IPE; they are chosen simply because they have become central to the contemporary study of globalisation and because they have considerable bearing on the subject matter of this book. Second, the three contributions identified are in many senses interrelated and provide a common pool from which scholars draw. 
Susan Strange's unique brand of IPE has unquestionably shaped the concerns and outlook of the field, and will continue to do so. Strange's work does, however, serve to demonstrate that there is not such a clear and stark divide between the orthodox and new ways of 'doing IPE'. In many ways Strange's vast and rich body of work constitutes a 'bridge' between the intentions and assumptions of scholars such as Robert Keohane and Robert Gilpin, and the agenda of the new IPE that she so clearly embraced in the first volume of the Review of International Political Economy (1994). This bridge was shifting and contradictory but persisted throughout her work. On the one hand, Strange was direct in her criticisms of orthodox scholars, as in her plea to 'Wake up, Krasner, the world has changed':

I would plead with my old friend to re-examine his realist assumptions about the units of analysis and the central problematic of international political economy. It becomes much more interesting to teach, to research and to write about when you drop the idea that states are the units of analysis and that war is the main problematic of the international system.

(Strange, 1994: 218)

Here, as in many other places in her work, Strange distances herself from a mainstream IR and IPE that 'assume the maintenance of order to be the prime if not the only problématique of the study' (1988: 14). On the other hand, however, appreciative critics have, nonetheless, suggested that Strange is 'prevented from realising the full potential of her radical ontology' (Tooze, 2000a: 287), that she wastes the opportunity to 'challenge international relations theory at its very core' (Palan, 1999: 128) and that she 'closes the Pandora's box that she has opened' (May, 1996: 184). Indeed, there is even the suggestion that she herself invoked multiple forms of 'realism' so that her 'work is torn by internal tensions' (Guzzini, 2000: 217). Strange's path to IPE is highly ambiguous, then. She must be credited with much of the impetus for the new IPE, and yet she closes off some of the avenues and approaches that are central to a genuinely critical ontology and epistemology.

Perhaps Strange's first order contribution to a new IPE is her challenge to the politics-economics dichotomy, achieved through the development of her ontology of structural power. Indeed, for Strange questions of power represent the very essence of IPE: 'it is impossible to study international political economy without giving close attention to the role of power in economic life' (1988: 23). IPE and power form a mutually constitutive relationship for Strange, it is not possible to study one without reference to the other. This is a considerable departure from the orthodox representation of power as the expression of state interests, a conception referred to by Strange as 'relational power' and criticised for its 'distinction between economic power and political power' (1988: 24-25). The opposition and distinction between political and economic power is apparently not a tenable one for Strange. The concept of 
structural power is her tool for breaking up the distinction: 'Structural power is the power to shape and determine the structures of the global political economy within which other states, their political institutions, their economic enterprises and (not least) their scientists and other professional people have to operate' (1988: 25).

So, for Strange, power in the global political economy does not rest with single unitary states, but is exercised by a number of public and private authorities through the structures of finance, security, production and knowledge. ${ }^{3}$ Strange opens up a number of possibilities with her identified dimensions of structural power. She makes it possible for sources of agency to be made more visible in IPE inquiry, and for this agency to be 'non-state' in nature, exemplified by her probing of the role of MNCs in the production structure (Stopford and Strange, 1991). She opens up the possibility for markets to be politicised in the sense of their 'making' by states and societies, for example her work on global financial markets (1997a; 1998a). Simultaneously, she raises the question of states becoming 'marketised', as in her work on the declining authority of the state $(1995 ; 1996)$. It is clear that for Strange IPE is not a rational, unemotional or objective field of inquiry, and that her subject matter is intrinsically human and social.

In identifying the dimensions of structural power beyond the conventional confines of security and trade (for Strange trade is a 'secondary power structure'), Strange also opens the door on a more heterodox IPE. In terms of issue areas, though she does not fully explore these in her own work, Strange extends our conventional notions of the realm of the 'political' in IPE with discussion of the activities of the mafia, consultants and accountants (1996), the roles of telecommunications and technology policy (1988) and environment and the biosphere (1994). In line with this apparent openness to issues in IPE, Strange consistently invoked the need for IPE scholars to open up to the insights of business scholars, economic historians, geographers and sociologists (1996: xv; 1994: 218; 1988: 15). Her remonstrations that IPE scholars should 'theorise from what they know' led her to argue that they should engage with those who 'know about' other realms of global social change. For Strange knowledge is essentially 'information', a commodity or resource that is possessed and used (May, 1996), leading her to invoke heterodoxy but to pursue this in an empiricist fashion, as 'data gathering'.

Finally, Strange's work was influential in focusing IPE on the dynamics of global social change. Her analysis of the changing shape of the state-market dialectic led her to pose the question 'who or what is responsible for change?', and to answer 'technology, markets and politics' (1996: 185). There is a clear attempt to address the issue of how and why change takes place in the GPE, and to extend the agency of change beyond unitary nation-states. Nor does Strange shy away from the normative implications of global change. For her the risk and uncertainty of global transformation is unequally produced, distributed and mitigated (1983; 1998b). 
Despite the groundbreaking nature of Strange's work, there are a number of constraints imposed by her approach that throw into question the promise of an open and 'unenclosed' field and place obstacles in the path of a new IPE as it is outlined by Craig Murphy and Roger Tooze, and as I conceive of it. The first problem concerns Strange's reinscription of the very dichotomy between politics and economics that she seeks to transcend. A number of passages illustrate this point:

Economics is about the use of scarce resources for unlimited wants ... Politics, though, is about providing public order and public goods. (Strange, 1988: 14)

The impersonal forces of world markets ... are now more powerful than the states to whom ultimate political authority over society and economy is supposed to belong. (Strange, 1996: 4)

The orthodox distinction between politics and economics is redrawn here. Politics is conceived in narrow terms as authority exercised in the provision of order and stability, and economics as the allocation of resources by private authorities. We begin to see how Strange might be categorised as 'hyperglobalist' (Held et al., 1999) or as holding a 'process-centred' view of globalisation. Her later work strongly asserts the triumph of liberal economics over state authority (politics as she sees it) and, fundamentally fails to 'reintegrate politics and economics' (Tooze, 2000b: 176).

Strange's conception of the nature of the political falls short of allowing us to conceive of everyday practices as political acts in the global political economy. Her work, in a sense 'adds agents' to IPE inquiry but without reflecting upon how we arrive at these agents or 'whom' they represent. We are urged, for example, to consider markets and technologies alongside states as agents of change (see Figure 2.1). In this 'flow diagram' representation of global social change technology is depicted separately and alongside states and markets, begging the question of how technology can be conceived as a realm that is separate and comparable to these realms. The model of social change represented by the flow diagram in Strange's (1991) analysis identifies agents acting through structures to produce 'outcomes'. The representation of social change is unilinear and deterministic, with contingency only arising out of different combinations of actors and structures that may affect the outcomes. The people, workers, firms and social groups inside the markets, states and technologies are simply invisible in this representation.

Of the four structures that are central to Strange's conception of global social change, it is the knowledge structure that has been most widely critiqued (Tooze, 2000a, 2000b; Palan, 1999; May, 1996; Cox, 1992a). Strange's conception of knowledge, as a resource of information that can be wielded or exercised, allows her to position the knowledge structure alongside the structures of production, security and finance. Knowledge, in this sense is an instrument in the global political economy just as a particular production 


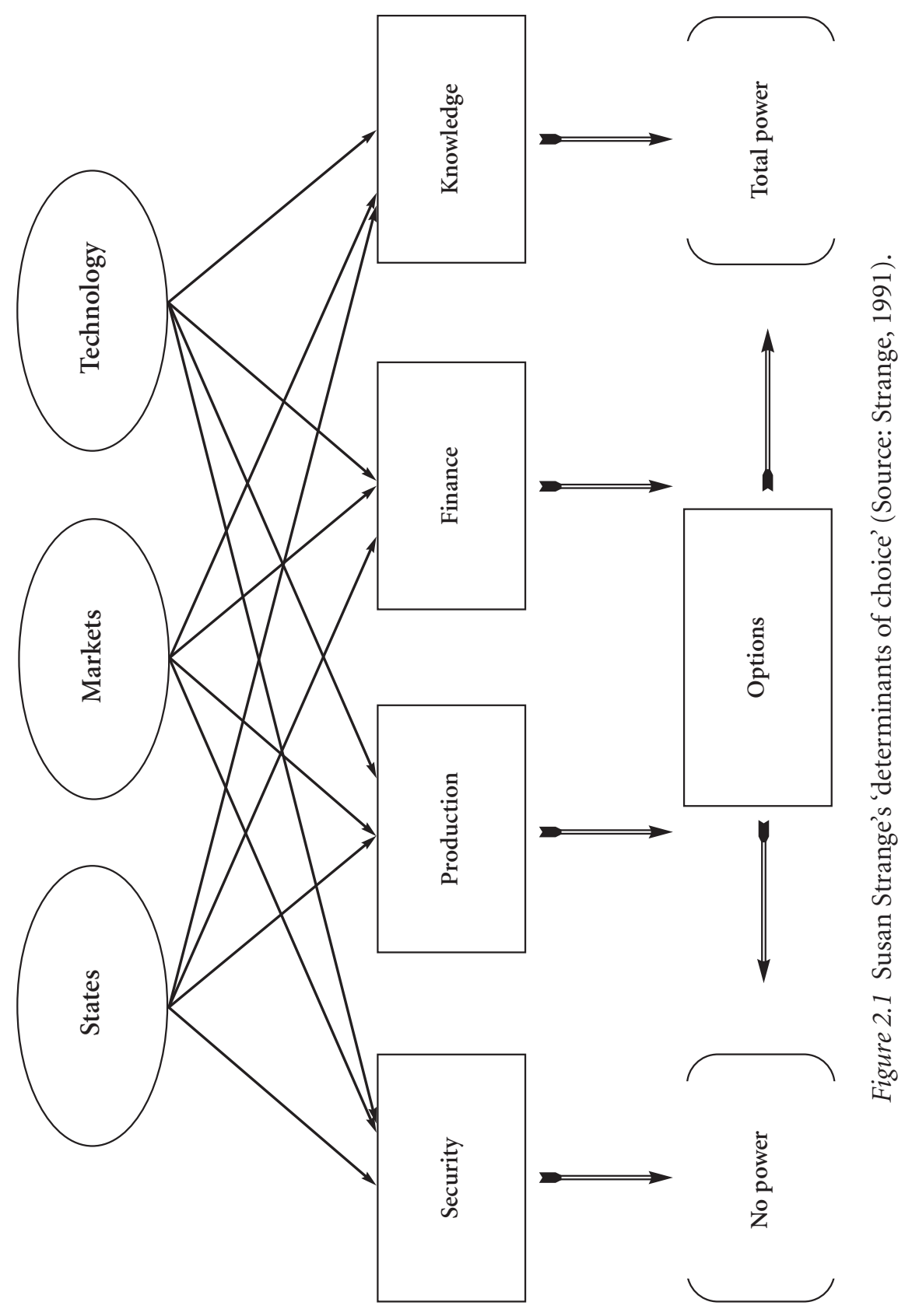


structure may be an instrument, for example of US hegemony (Rupert, 1995). If Strange had embraced the full implications of a new IPE ontology then the knowledge structure would have to surround and suffuse the agents and structures she depicts. If knowledge is also to imply 'intersubjective meanings' and frameworks of thought, then surely the states, markets, technology and structures identified by Strange would have, to some extent, to be produced and reproduced by our frameworks of thought. So, for example, dominant ideas about how society should be organised at a given historical conjuncture will both inform and reflect the interactions of structures and agents. Agents are reflexive; they have the capacity to reflect upon, challenge or reproduce the structures that they confront. Tooze finds it 'ironic that it is precisely her view of knowledge and ideology' that precludes Strange from achieving a reflectivist mode of thought in IPE (2000a: 176). If there is a principal missing element in the Strange path to IPE it is the failure to adequately explore the relationship between power and knowledge, two concepts that she paradoxically inscribed deeply in the collective IPE common sense.

\section{Polanyian insights and the new IPE}

As the new IPE has sought to bring critical insights to the study of global social change, a number of scholars have drawn upon the work of economic historian Karl Polanyi. ${ }^{4}$ The dominance of linear and deterministic understandings of the relationship between politics and economics has led some scholars to search for a society-centred theory from which to develop their critique:

The inclusion of civil society together with a strong historical dimension constitute important contributions by Polanyi to IPE. In spite of its ambition to integrate the "political" and the "economic", current IPE gives only a partial view of societal change. We can perhaps define a New International Political Economy as attempts to go beyond the statemarket contradiction. (Hettne, 1995: 5)

We can read the appropriation of Polanyi's writings by the new IPE as a reopening of the 'Pandora's box' that is closed by Strange. Polanyi's work appears to offer a route into an understanding of the historical and political contingency of market expansion and social transformation. From Polanyi's rich and diverse writings, contemporary IPE has drawn out two central themes which it finds useful in the study of contemporary global social change: the embeddedness of economy in society and the 'counter movement'. If we are to use Polanyi's insights to move us closer to the contestation of global social change, then it is important to consider the context and problematics of IPE's retrieval of his thought.

The central question of Polanyi's The Great Transformation was to explore the historical transformation of nineteenth-century capitalism, and to explain the social effects of an imposed 'self-regulating' market economy: 
Man's economy, as a rule, is submerged in his social relationships ... Neither the process of production nor that of distribution is linked to specific economic interests attached to the possession of goods; but every single step in that process is geared to a number of social interests which eventually ensure that the required step be taken. These interests will be very different in a small hunting or fishing community from those in a vast despotic society, but in either case the economic system will be run on noneconomic motives. (1957: 46)

The primacy of society and social relationships in Polanyi's analysis is evident here. The market forces of the economy cannot, in Polanyian terms, be understood separately from the society in which they are situated, so that 'the economic order is merely a function of the social, in which it is contained' (1957: 71). Thus, for Polanyi a market is a politically and socially constituted entity, made in particular ways in defined historical places and times. $\mathrm{He}$ presents a powerful critique of the economic determinism that says that societies are shaped by the actions of rational economic man, branding this an 'economistic fallacy' (1957: 111-129). A laissez-faire market order is 'nothing natural' and requires a constant process of reproduction and reinforcement, not least by the actions of the state (1957: 139). Viewed in this way politics and economics become mutually constitutive within a context of social relations. The creation of markets in land, labour and capital, for example, are held to represent 'fictitious commodities' (1957: 68) that cannot be traded without agitating and disrupting the human and social fabric. The commodification of labour represents for Polanyi the central contradiction of market society, both the 'core' and the 'core weakness' of its organisation (Block and Somers, 1984: 57). As Polanyi has it:

To argue that social legislation, factory laws, unemployment insurance, and, above all, trade unions have not interfered with the mobility of labour and the flexibility of wages, as is sometimes done, is to imply that those institutions have entirely failed in their purpose, which was exactly that of interfering with the laws of supply and demand in respect to human labor, and removing it from the orbit of the market. (Polanyi, 1957: 177)

Markets for labour do not occur as natural or self-regulating realities. Their uneasy relationship with the human needs and practices of daily life is mitigated through sets of social institutions that must be constantly produced and reproduced if the contradictions are to be masked. Polanyi is not, however, advocating the taming of capitalism through the protective layer of social institutions or, as Hannes Lacher puts it he should not be regarded as a 'prophet of interventionist welfare capitalism' (1999: 314). At the heart of Polanyi's reading of industrialisation is the identification of an intractable contradiction between the social and human activities of 'life itself' (1957: 72), and the dictates of the market: 
The idea of a self-adjusting market implied a stark utopia. Such an institution could not exist for any length of time without annihilating the human and natural substance of society; it would have physically destroyed man and transformed his surroundings into a wilderness. Inevitably, society took measures to protect itself, but whatever measures it took impaired the self-regulation of the market, disorganized industrial life, and thus endangered society in yet another way. (1957:3)

Polanyi does not offer the oft-cited 'counter-movement' as a solution or 'source of resistance' to the ravages of the market economy. Rather, he indicates that the inherent tensions and agitations of market society demand continuous action and intervention to run interference between economy and society. Yet, this interference in itself is unsustainable since it disrupts the assumptions on which a market is based. The logics of industrial capitalism and human life cannot be reconciled in this reading; they are inherently provocative and contested. This conception of contradiction, provocation and ambiguity, as Lacher (1999) points out, has been rendered invisible and obscure by most appeals to the 'counter-movement' in the new IPE texts.

New IPE scholars have appropriated the concepts of 'embeddedness' and the 'counter-movement' in a number of ways. What we might broadly consider to be an institutionalist strand of thought has drawn on the concept of embeddedness to counter the economic determinism of the globalisation thesis. In this reading global economic forces are re-embedded in nationstates (see Hollingsworth and Boyer, 1997; Hollingsworth, 1998) and MNCs are embedded in national systems of production (see Grabher, 1993; Sally, 1994; Zysman, 1996). The relationship between Polanyian political economy, historical sociology and comparative institutionalism is, thus, an intimate one. ${ }^{5}$ The new IPE has embraced this appropriation of Polanyian analysis on the grounds that it contextualises global social change, apparently politicising through attention to the social institutions that may 'redirect' global forces. However, the neo-Polanyian use of embeddedness has imposed a stasis that is not evident in Polanyi's work. His sense of agitation and tensions within the economy-society relation is absent from much of the neo-institutionalist strand of the new IPE. In its place we get the image of the forces of globalisation being filtered through the distinctive social institutions of nationstates. As Block and Somers have it, 'global opportunity structures shape what is possible for particular governments', while a 'national opportunity structure' shapes 'what is possible' for societies (1984: 74). The dichotomies of economics/politics, exogenous-global/endogenous-national, are thus reinscribed and globalisation is presented as a 'project' directed through national institutions.

It is Polanyi's concept of a 'counter movement' that has captured the attention of a large swathe of new IPE scholars. In a supposed era of globalisation there is considerable interest in a theory that potentially says 'societies will seek to protect themselves' from the 'disembedding' of economics from 
the social realm (Bernard, 1997: 79). The idea that there may be space and opportunity for resistance to globalisation or the possibility to shape global futures is a seductive one, and has led scholars to identify Polanyi as a conceptual kindred spirit (Mittelman, 2000: 8; Rice and Prince, 2000: 171). Polanyi's society-centred political economy does undoubtedly open up the possibility for IPE theorists to discuss the responses of civil society groups and new social movements to the vacillations of globalisation. However, it is important to recognise that this is not the 'counter-movement' envisaged by Polanyi, who leaves the question of social order wide open. Polanyi's work does not conceive of an emancipatory space for the contestation of liberal logics and the negotiation of alternative futures (though, of course, this does not preclude others from reading him this way). What should not be forgotten is that Polanyi demands that we direct our attention to the 'continuing contradictions between society and the market' (Lacher, 1999: 323).

The appropriation of Polanyi's notion of a 'counter-movement' is not sufficient in itself to further a new and critical IPE that can account for contingency in global social change. Indeed, it is not a 'solution' or 'strategy' that is implied by Polanyi, but rather presents IPE with an opportunity to further politicise and historicise its knowledge. In the terms of this book, Polanyi's work is a constant reminder that markets for labour are created and reproduced over time, that they are contradictory and in tension with the lives of the people that they embody and that social change is made and contested in ways that are contradictory and contingent. A critical and historicist ${ }^{6}$ reading of Polanyi demands that we disrupt the simple notion that global forces have disembedding effects on societies, to reveal the tensions that pervade the economy-society relation and the multiple interpretations and experiences that individuals and social groups may have of the perceived disembedding.

\section{Gramscian insights and the new IPE}

For Gramsci, it is the ensemble of social relations configured by social structures which is the basic unit of analysis, rather than individual agents, be they consumers, firms, states or interest groups. (Gill, 1993: 25)

For those IR and IPE scholars who have interpreted Gramsci's work for contemporary problematics, ${ }^{7}$ the first order questions are concerned with society and social transformation. In the Gramscian ontology, social relations and social structures are the primary elements to be considered, for they alone constitute the limits of the potential space for change to take place. Of course, while for Gramsci the central terrain of social organisation was the national social formation, for his IPE interpreters the terrain may be transnational or global (Germain and Kenny, 1998). Gramsci's work has been viewed by new IPE scholars as offering the potential to critique linear and determinstic accounts of social change via a critical focus on the capacity of political agents to com- 
municate with, mobilise and induce change in society. Social change thus derives its shape and meaning as it is played out by agents acting within and through social structures. In this way 'reality' becomes a 'product of the application of human will to the society of things' (Gramsci, 1971: 171). The intersubjective realms of ideas, knowledge, theory and social institutions thus become central to processes of social transformation (Gill, 1993: 23), and may engender or constrain social contestation, conflict and dissent (Femia, 1981: 35; Rupert, 1995: 13).

For the neo-Gramscian scholars, the study of change in IPE has tended to focus on the reciprocal relationships between forms of state, social forces and world orders (Cox, 1981). Drawing on Gramsci's notion of a historical bloc (blocco storico), social transformation is viewed as complex, contradictory and multi-faceted. Murphy (1994) interprets Gramsci's historical bloc as an apparently unified social order that may be compared, using an architectural metaphor, to a block of flats and shops that represent an underlying order. When a historical bloc is stable and hegemony is built on coercion and consent, life goes on 'as it should' (Murphy, 1994: 20). But when the bloc is in crisis and one of its facades begins to crumble there is space for the structures to be 'rebuilt or reclaimed' (1994: 29). Murphy's interpretation of Gramsci serves to problematise representations of social institutions as given or static entities. The 'project' of global restructuring thus becomes part of a wider fabric of social power relations that may be cut or hewn in new forms, but not without tension or contest:

The active politician is a creator, an initiator; but he neither creates from nothing nor does he move in the turbid void of his own desires and dreams ... What 'ought to be' is therefore concrete; indeed it is the only realistic and historicist interpretation of reality, it alone is history in the making and philosophy in the making, it alone is politics. (Gramsci, 1971: 172)

The contests and bargains over what 'ought to be', in the sense of the shape of a historical bloc or how society should be organised or reorganised are, thus, for Gramsci and his IPE interpreters, the essence of politics. For a study such as this, seeking to reveal the contests and struggles that surround and suffuse the restructuring of work, the Gramsci-derived insights open up the possibility of a conception of contestation in social change. In our terms of reference the social forces that intersect workplace, state-society and world order become key sources of contingency in social transformation (Cox, 1987; Harrod, 1987). Production and work are conceived in a broad sense, with production representing 'life, for the dispensation of energy (work) which results in life (product)' (Harrod, 1997a: 109). IPE studies have drawn upon Cox's and Harrod's theses of power and production to demonstrate the production and reproduction of webs of social power relations over time. As Rupert has it, attention is directed to the 'processes through which power has been produced' and the 'conflicting social power relations which at once underlie and make possible that production, and which also problematise its 
long-term reproduction' (1995: 1). Gill's account of the elite that constitutes a disciplinary set of neo-liberal social forces, similarly emphasises the web of power relations binding international capital, accountants, consultants, large firms and workers in supply chains (1995: 400). There would seem to be potential here to explore the ongoing social contests that paradoxically underpin a particular historical bloc, yet also raise the contradictions that are likely to call it into question.

As with all strands of IPE inquiry, the neo-Gramscian 'school' cannot be uncritically applied to studies of global social change. While they open up critical avenues of inquiry and seek to 'politicise' accounts of globalisation, they do this in a particular way that leaves other avenues opaque and uncharted. A central problem with the uncritical adoption of Gramscian insights is the sustained separation of an apparently coherent 'global elite' from potential, and apparently less coherent 'local resistors': 'The writings of open Marxism present political power as a thing formed outside social formations, in the rarefied atmosphere of the world economy ... imposing closure from the start on active politics in the world economy, relegating struggles to the sphere of national social formations' (Drainville, 1994: 120-121). The image is one of a transnationally 'hyperliberal thinking' organised elite directing a topdown project, that constrains nationally located social groups who may 'resist'. The 'global' is thus reinscribed as a realm of expertise, technical knowledge and strategy, while the 'local' is a peripheral space of everyday social relationships. Given that I seek to disrupt the reflex of representing societies as 'responding to' the imperatives of globalisation, I suggest that it is just a short step from 'responding' to 'resisting. In both formulations, societies and social groups are separated from, and opposed to, some ethereal process or project of globalisation. Power is 'wielded' in both instances, either by the promoters of the project, or by the resistors in their 'anti-globalisation' strategies. ${ }^{8}$

Just as social change is conceived by the neo-Gramscians in terms of social forces within a historical bloc, so it is also presented in 'periods' of transition, from one set of structures to the crisis, and then to the rebuilding. The dichotomies of the IPE orthodoxy are replaced by a series of new dichotomies that characterise social change in terms of 'order/disorder', 'Westphalian/postWestphalian,' 'hegemony/post-hegemony ${ }^{10}$ and 'starting-point/end point." The assumption that restructuring and social change takes place in a crisisridden interstice between two stable orders raises significant questions. Are we to distinguish strategic formal restructuring programmes from the more general and continuous rhythms of social change? The breaking up of social change into defined periods serves to further marginalise certain issues in IPE inquiry. The realms of finance, production and technology are privileged above 'everyday' realms of work and social practice since the latter can only change at the margins or in the gaps in the historic bloc.

The neo-Gramscian frameworks offer one route into the problematising of transformations in workplace, state-society and world order. However, 
some of the doors that have been closed by these scholars can be pushed further ajar. There is a particular need to identify ways to break open the opposition of 'perpetrators' and 'resistors' of globalisation. I am reminded of a report from the Seattle protests that asked 'Did the protester who was filmed kicking lumps off the Nike sign while wearing Nike shoes see the irony?' (Elliott, 1999). In this allegory the neo-liberal elite and the actions of the protester are closely interwoven. In our everyday practices we rarely consciously adopt a reinforcing or challenging role in relation to the shape of social change. Further, and in order to challenge the periodisation of global social change, we need to be able to contemplate how programmes of restructuring communicated by international organisations, governments or corporate actors intersect with individual and collective social understandings and practices. Such a focus can begin to challenge the notion that power is wielded in the global realm and 'received' or resisted in the local.

\section{An international political economy of social practice}

It is clear from the above analysis that the new IPE has sought to expose and transcend the bounded terrain of orthodox IR and IPE, exploring alternative political terrain through firms, institutions, financial centres, technology, and to a lesser extent labour and work. Susan Strange's questions of the nature and sources of power, the neo-Polanyian highlighting of the contradictions of market society and the neo-Gramscian emphasis on social forces within and across states and world orders - taken together they lead us to reflect upon global social change in particular ways. Global social change potentially becomes a contested, contingent and politicised process that is expressed, first and foremost, through everyday social practices. However, the boundaries of IPE knowledge that have been agitated by the new IPE do leave us short of what Sinclair has termed an 'IPE of the commonplace' (1999: 164). The new IPE has tended to focus predominantly on the politics 'at the top', residing in the actions and interests of global elite groups and organisations. Where everyday modes of political action and expression are discussed, these have been located in a 'local' or 'national' sphere. Yet, it is in the everyday aspects of people's lives that global social change is interpreted and experienced. It is in the realms of everyday thought and practice that competing interests confront one another, and where the contradictions and tensions of social transformation are expressed. Indeed, we might say that the 'everyday' realm is one where the boundaries of national/transnational, local/global, economics/ politics and states/markets are both constituted and confounded.

In order to bring IPE close to the social practices that characterise our everyday lives, three further steps can be taken. The first is a response to the call for a 'historicised IPE' (Amin and Palan, 1996; Amoore et al., 2000), that is to say a representation of social change, and all knowledge of social change, as historically contingent. The second is a challenge to the prevailing IPE concep- 
tion of power as something that is 'held' or 'wielded' by particular elite agents in a global sphere. The final step proposed here is a conception of everyday social practices as a key terrain of politics and, in particular, as the central spaces in which global restructuring is played out and contested.

\section{Historicity and contingency}

I began this chapter by reference to Cox's claim that IPE is critical theory by virtue of its standing apart from structures in order to explore their historical constitution and transformation. What does it mean to consider social structures and their transformation to be 'historically constituted'? And is this a sufficient step towards a new IPE that is sensitive to historicity and contingency? ${ }^{12}$ Certainly the new IPE has made claims to an epistemological selfawareness that infers that all IPE knowledge is historically constituted. Yet, the historical turn in IPE has been, in the main, rather limited. The work of the historical sociologists (see Hobson, 1997; Skocpol, 1984), and others who advocate a 'historicised IPE' (Amin and Palan, 1996), can be said to add history simply as an adjunct to the study of structure and agency. That is to say, they consider the historical context of the agency of human beings through a sensitivity to their role in the 'building' of institutions, and the constraining effect of these institutions on their lives. Their concern is thus with what Mills calls 'historical push and shove', and Amin and Palan term the 'fixity and flow of social evolution' (1996: 211).

Such invocations to 'consider history' fall some way short of allowing us to consider global social change as substantially constituted and contested through the consciousness, reflections and experiences of people. For this we require a historical mode of inquiry, an approach that views social structures and institutions as 'the historically apprehended knowledge of the particular circumstances of the human condition' (Amoore et al., 2000: 56). Viewed from a historicist vantage point, Strange's knowledge structure is recast as a domain that suffuses all other structures, thought and action. The configurations of states-markets, economics-politics, domestic-international and structureagency are understood through the dimension of human knowledge of these relationships:

The real is not "out there" and thought within the quiet lecture theatre of our heads, "inside here". Thought and being inhabit a single space, which space is ourselves. Even as we think we also hunger and hate, we sicken or we love, and consciousness is intermixed with being; even as we contemplate the "real" we experience our own palpable reality. (Thompson, 1978: 211)

We are thus reminded of the nature of IPE as webs of interrelationships of which reflective human beings form the key constituent elements, and within which we (and the subjects of our research) act, interact, experience and 
understand. From an extensive body of work that we may broadly term 'critical history', ${ }^{13}$ I draw out the themes that offer insights to the furthering of an IPE of social practice.

First, a historical mode of thought directs attention to the act of reflection that connects agents with frameworks of thought and action (Iggers, 1995: 131). Agents and structures do not simply push and pull one another through periods of social change, rather they are mutually constituted through acts of reflection, what Collingwood terms 'thinking about thinking' (1946: 307). Others, from sociological perspectives, have developed the concept of 'reflexive modernisation' to refer to the 'changing relationship between social structures and social agents' (Beck, 1992: 2; see also Giddens, 1990). Such readings of history share a view of human beings as participants in the making of social transformations. As Collingwood has it 'thought is not mere immediate experience but always reflection or self-knowledge, the knowledge of oneself as living in these activities' (1946: 297). The significant contribution that this mode of knowledge can make to the new IPE is that it grounds global social change in the reflective self-understandings that people have both of themselves and their circumstances and surroundings. Global social change does not simply 'happen to' people, it is experienced, interpreted and lived. The thoughts and actions of those living in the production structure, for example, become at least as central to the reproduction or undermining of that structure as the abstract entities of states, firms and technologies are currently assumed to be.

Second, a historical mode of thought can shed light upon the role of the historian, researcher or IPE scholar in the constitution of knowledge about 'our world'. Carr reminds us that the historian is also a participant in the process of change she or he observes and documents: 'The historian, then, is an individual human being. Like other individuals, he (sic) is also a social phenomenon, both the product and the conscious or unconscious spokesman of the society too which he belongs; it is in this capacity that he approaches the facts of the historical past' (Carr, 1961: 35). Carr thus reminds us that as we observe, write or teach about society, we also exist within, interpret and experience its dynamics. The interpretative choices of historians, influenced by their experiences, their 'history', will be reflected in the issues and subjects that are selected for documentation and theorisation. In an era that is persistently labelled 'global' it is particularly significant that we reflect on the experiences and perceptions that we bring to inquiry. It becomes possible to account for globalisation as one particular representation of global social change, and one that can be interpreted and expressed in numerous and contingent ways.

Finally, attention to the historicity of knowledge reveals the interpretative nature of all inquiry. History, for Collingwood is the 'science of res gestae, the attempt to answer questions about human actions done in the past' (1946: 9). Carr's (1961) retrieval of Collingwood's ideas captures the 'philosophy of history' as concerned with the interrelationships between the past and contemporary 
thought about the past. For him, history is given shape and meaning by 'seeing the past through the eyes of the present and in the light of its problems' (1961: 21). Human activity is made intelligible through acts of reflection that reenact possible past social meanings on a stage that is lit by our contemporary experiences and understandings of social change. From this perspective, understandings, interpretations and experiences of global social change are as 'real' in concrete historical terms, as the technological and economic flows that so many IPE theorists seek to account for.

In terms of a wider conception of global social change, a historicised reading makes visible the open-ended and contingent nature of the restructuring of social practices. In the realm of work these insights are particularly significant. Following the historical mode of thought employed by E. P. Thompson $(1978 ; 1980)$, we are led to view the material restructuring of the production process as intimately bound up with the everyday histories of the workplace and understandings of workplace realities. Of course, this does not mean that transformation is impeded (Femia, 1981). Rather, that any attempt to construct a 'project' of the flexibilisation of work does not simply confront the material factors of the production process, but also the understandings and shared frameworks of thought between the people that make this process. A project of restructuring is one expression of how change should be ordered, but it is not the only one and it makes sense only when played out through social practices, where it may mutate and take on a very different or unintended form. In this sense, what is often considered to be 'history from below' is not in any meaningful sense separate from a global imperative 'from above', since it is in daily histories that global imperatives become contested and reorganised so as to be understood.

\section{Power and agency}

IPE, as I have argued, has generally failed to recognise the agency of non-elite groupings of people in its understandings of global social change. It has had a particular blind spot with regard to workers and their relationship to the power relations that suffuse processes of change. Where labour and work do feature in the new IPE this has predominantly been in terms of their assumed 'powerlessness' in the face of a global restructuring 'project' that is executed by the 'powerful' neo-liberal elites. A key source of the invisibility of work and workers in IPE lies in the conception of power that dominates inquiry. Power is predominantly considered to be a commodity or resource that is exercised by particular agents over the lives of others. Thus, for much of the IR and IPE literature 'the capacity to wield power as a resource over other agents is an important proviso of agency' (Campbell, 1996: 11). Agency is in itself defined in terms of the ability to hold and apply power, and for those considered 'powerless' agency is denied and subjects are considered of peripheral importance to the field of study. Such conceptions of agency, found particularly in 
neo-Gramscian conceptions, are exacerbated by the identification of 'global' and 'local' levels of agency, where the global becomes the source of restructuring strategies, and the local has agency only insofar as it responds or resists through counter-strategies of its own. Technologies are, for example, represented as having agency in a global sphere that is simply 'received' 'on the ground'. Where IPE has sought to reflect on the agency of non-elite groups these are also assumed to be 'on the ground', such as in the responses of labour groups to the global strategies of firms.

An IPE of social practice must reinvigorate the 'openness' that is promised by the new IPE to reflect upon alternative conceptions of power expressed in philosophical and critical sociological writings. In the first instance power as an entity that is held, plotted or wielded is problematised. Where power in IPE is most commonly represented as structural capabilities that constrain and limit the actions of others, it becomes more fluid in the writings of Michel Foucault: 'Power is not an institution, and not a structure; neither is it a certain strength we are endowed with; it is the name that one attributes to a complex strategical relationship in a particular society' (1980a: 93).

Power thus becomes a network or matrix of forces that operates through society and social relationships. In this way power is not simply a static matter possessed by some individuals to limit others, but is practised in a more mobile, subtle and intricate way. Power moves, circulates and shifts (Bleiker, 2000: 134); it is 'elaborated, transformed, organised' (Foucault, 1982: 224). It is thus not possible simply to reduce power to a named group, individual, institutions or 'actor', as many of those seeking to identify the architects of globalisation would wish to do. Agents and institutions are undoubtedly central to the exercise of power, but they do not personify the source of power itself. Thus, states, firms and international corporations, for example, may through their actions define a field of possible future actions, but they do this as part of a wider web of power relations. In this sense 'one must analyse institutions from the standpoint of power relations, rather than vice versa' (Foucault, 1982: 222). Viewed in this way an apparent 'project' of the flexibilisation of work is not controlled or exerted in any simple linear sense. The firm, the policy agenda, the industrial relations institutions, become forums for webs of power-knowledge relations that actually extend the 'limits' of the institution.

The conception of power and knowledge in a correlative, and not a causal relationship (Dreyfus and Rabinow, 1982: 203), raises significant questions for Strange's (1988) distinction of the production and knowledge structures. ${ }^{14}$ If we see power and knowledge as 'tangled up in the knot of a "not without", (Keenan, 1997), then their separation as a resource (power) versus a means of power (production and knowledge) is problematised. In our terms, if we seek to explore the knowledge and techniques that have defined and managed the flexibility discourse, then we cannot observe these concretely without analysis of the webs of power relations that suffuse the restructuring of work (and vice versa). This brings us to the question of levels of analysis and 'how' and 'where' 
such power relations should be studied. A sustained separation of an 'outer world' of elite world politics from an 'inner world' of the localised politics of struggle obscures the 'transgression of these fine lines' (Walker, 1994: 700). A number of studies have identified 'transversal struggles'15 or 'infrapolitics' as the immediate struggles that characterise 'globalised life' (Campbell, 1996: 24; Bleiker, 2000: 130; Scott, 1990: 183). Viewed in this way 'people criticise instances of power which are the closest to them ... They do not look for the chief enemy, but for the immediate enemy' (Foucault, 1982: 211). In our terms, whilst government policy statements, corporate strategies and indeed the 'antiglobalisation' groups, may communicate globalisation as the 'chief enemy', their actions within networks of power focus on their immediate environs, effectively demonstrating the illusory separateness of an exogenous global level.

A conception of power as a network or chain of relations thus takes the politics of global social change out of the sole domain of elite agents. Of course, the strategies and actions of bankers, policymakers and corporate managers are significant in global social change, but they cannot be adequately analysed in the absence of the social power relations of which they are part. In this sense 'contesting globalisation' is not primarily about the outlining of a 'counterhegemonic' project to confront an identifiable neo-liberal restructuring agenda. Rather, it is about exploring the web of power relations that apparently underpin the 'project', revealing the contradictions and tensions that are manifested through everyday social practices.

\section{Social practice, social space and the 'everyday'}

Amidst the clamour of voices seeking to understand globalisation, a small group of scholars has drawn attention to the emerging social relations of globalisation and the structured social practices that make these possible (Sklair, 1991; Germain, 2000; Jones, 2000). However, the existing work that comprises this embryonic perspective has focused almost exclusively upon the social practices of elite groups, thereby reinforcing the idea of a global project, albeit one that has become entangled with social relations. By contrast, the perspective advanced here views global social change as experienced, given meaning, reinforced and/or challenged in the everyday structured social practices of individuals and groups, such that globalisation is marked by contestation over the reality and representation of social change. Such a perspective rests upon a conception of 'everydayness' and 'everyday life' that does not locate itself primarily in supposed 'ground level' activity or the 'local' dynamics of global change. Rather, the everyday is conceived as a 'common denominator of activities, locus and milieu of human functions ... the uniform aspect of the major sectors of social life: work, family, private life, leisure' (Lefebvre, 1987: 10, see also Lefebvre, 1991a). The everyday is thus a 'contested place' (Davies and Niemann, 2000: 3), a realm of tensions and contradictions, where the banale and routine meet the potential for social transformation: 
The quotidian is on the one hand the realm of routine, repetition, reiteration: the space/time where constraints and boredom are produced ... Even at its most degraded, however, the everyday harbors the possibility of its own transformation; it gives rise to desires which cannot be satisfied within a weekly cycle of production/consumption. The Political is hidden in the everyday, exactly where it is most obvious: in the contradictions of lived experience, in the most banal and repetitive gestures of everyday life - the commute, the errand, the appointment. (Kaplan and Ross, 1987: 3)

It is in the realm of the everyday that our understandings, experiences and meanings of globalisation are made. To locate the political, as many IPE scholars do, narrowly in the actions of states, firms, organisations or social movements, is to miss this 'commonplace world of everyday experience', where conflicts and contests take place, and 'change is most widely felt' (Sinclair, 1999: 158). Indeed, far from underestimating or denying the emergence of globalised ways of life, a focus on the everyday reveals 'the concrete production of internationalised social relations in the daily practices of workers, families or consumers' (Davies and Niemann, 2000: 6). The everyday sphere thus challenges the mode of thought that separates a 'global' sphere of legitimate IPE inquiry from a 'local' sphere of empirical evidence to support claims to globalisation, 'constructing global capitalism as a more abstract system than it really is' (Thrift, 1995: 21). The idea that globalisation is 'bigger than us' and, therefore that social change is always a result of external forces, is thrown into question. As Bruno Latour depicts it: 'A giant in a story is not a bigger character than a dwarf, it just does different things. The same two metre-square print may represent a battlefield or an apple; no one will say that the first is bigger and more encompassing than the second' (Latour, 1988: 30).

IPE's claims to be concerned with the spatial 'bigger picture' of the 'whole world' rather than 'particular parts of it' (Strange, 1997b: 182) are thus challenged by the insights of Latour's actor-network theory. ${ }^{16}$ Coupling these insights with those of Lefebvre, globalisation becomes one conceptual means of identifying and naming social change, but one that disguises the myriad of conflicting and contingent meanings and experiences that are translated in networks of everyday social life. If we conceive of 'social space as a social product' (Lefebvre, 1991b: 26), then there cannot exist a global space that is independent of the actions and contests of people engaged in social practices. The spaces of states, firms and organisations conceived by IPE cannot simply 'contain' social relations and practices, nor do they exist prior to these relations and practices. The restructuring of such spaces cannot, therefore, be predicted or linear in nature. Lefebvre reveals multiple layers of space via three dialectical 'moments of space' within and between which people may constantly move: spatial practices, the realm of perceived daily reality and the interaction with 'material and physical flows' (Agnew and Corbridge, 1995: 7); representations of space, the realm of space as conceived by 'scientists, planners and 
social engineers'; and representational spaces, the realm of space as lived or imagined (Lefebvre, 1991b: 39).

Workplaces can be seen as embodying all of these spatial moments, of which the idea of an 'imperative' of flexibility captures only one particular representation of space. Drawing on Lefebvre's terms, the workplace as a conceived space may be reinforced, contradicted or undermined by perceptions and lived experiences. The restructuring of work does not simply confront a material reality contained within unitary states and firms, but a set of human and discursive representations (du Gay, 1997). As Kaplan and Ross have it: 'institutions, codes and paradigms are not abstract constructs confronting us in some official "out there". Nor do we come to institutions alone. We live them in historically specific ways ... as collective or virtually collective subjects' (1987: 4). We can see that the spaces that IPE terms 'national political economies' or 'multinational corporations' or 'social movements' embody an array of social spaces and networks. We can never consider these spaces to be complete or static, since they are continually made and remade: 'All networks of social relations, whether we are talking about capitalism, or firms, or any other institutions are incomplete, tentative, and approximate' (Thrift, 1995: 33).

The workplace thus does not simply provide an institutional 'context' for social change. It does more than 'trace out the traces of spaces' (Bingham and Thrift, 2000: 299). It is shaped by the articulation of conflicts, tensions and compromises that are played out in social practices. An IPE of social practice challenges the unitary and abstract conception of states and markets interacting to produce global social change. The 'state' and the 'market' are opened up to reveal the webs of social relations that agitate their parameters. Work (and by implication the restructuring of work) is conceived as everyday structured social practice through which the emerging social relations of globalisation may be enabled, contested or confounded.

\section{Conclusion}

While the previous chapter explored the linear and imperative construction of social change that underlies the discourse of labour flexibility, the present chapter mapped out the terrain of social change as conceived in contemporary IPE. I have argued that the new IPE has positioned the understanding of global social change centrally in its inquiry, a crucial departure from the emphasis of orthodox IPE. The attempt to transcend state-centrism, to politicise and historicise the study of globalisation, and to create an 'open' field - all serve to disrupt teleological and deterministic representations of social change. Though I seek to take some of the new IPE insights forward into the chapters that follow, I do so critically and with caveats. Susan Strange's conceptualisation of structural power, and particularly the firm as a powerful agent, has raised the profile of production in IPE inquiry. Yet, her states and firms take on the status of 'power wielders', leaving the webs of power relations 
that surround and suffuse them less visible in analysis. To uncover the powerknowledge webs that run through the restructuring of work, as I have argued, requires further steps to be taken.

From Polanyian frameworks in the new IPE, this study embraces the assertion that labour is a 'fictitious commodity', that labour markets are politically and socially produced and reproduced over time, and are made and defined in particular ways in different places. However, I have argued that caution should be exercised in the use by IPE of the concept of the 'double movement'. To argue that societal dissent and organised resistance will flow automatically from the damaging forces of the market is, paradoxically, to remove the politics from understandings of restructuring. It is, by contrast, in the contradictions highlighted by Polanyi that we find the politicisation of social change. This book is concerned with revealing the contradictions and tensions that run between markets for labour and experiences of work in human and social life.

Similarly, from neo-Gramscian analysis, the social forces that intersect workplace, state-society and world order become key sources of contingency and contestation in social transformation. This study, however, rejects the notion that globalisation is a project driven by the interests of global elites, and resisted by the actions of local groups. Where aspects of global restructuring do become represented as 'project-like', as in the flexibility thesis, this project is not simply 'executed' and absorbed by societies. Rather, it is translated, given many different meanings and lived out in diverse ways. Again, these steps require some further conceptual doors to be nudged open. If the promise of openness and heterodoxy is to be fulfilled in IPE, then there is a need for some conscious reflection on wider discussions of social change, and the avenues they may open. In particular, this chapter has identified the need to challenge IPE's conceptions of power as 'wielded', and knowledge as a commodity or resource that is simply possessed and traded. I have argued that if we can transcend these conceptions we can challenge the hierarchy of issues in IPE that says finance, technology and production 'matter' because they are sources of power, whilst work and everyday life are only the 'effects' of wider transformations.

My central argument in this chapter has been that an IPE of social practice can reveal the politics and contingency of globalisation as it is characterised by contests over the reality and representation of social change. I have mapped the terrain of an IPE of social practice, as I see it, through the intertwining of three strands of thought on social change. Each has particular implications for the study of the restructuring of work in the chapters that follow:

1 Historicity and contingency - Following a historical mode of thought, we are uniquely placed to account for, and to understand global social change, as our everyday lives are bound up with its rhythms. It is not separate from us, nor is it greater than us or beyond apprehension by individuals and social groups. Viewed in this way, the apparent 'project' of the restructuring of work is simply one expression of how social change is 
ordered, and it is not the only one. The transformation of work is historically contingent. Thus, globalisation and flexibility become imbued with different meanings in different places. Such meanings, though often having the appearance of coherence, are contested within and across their boundaries. In the chapters that follow I explore the diverse interpretations and experiences of restructuring within and across state-societies, often understood as 'national capitalisms'; within and across firms, often considered as 'actors' rather than sites of struggle; and by individual and groups of workers.

2 Power and agency - In the analysis of global social change it is insufficient to locate power primarily in the hands of the 'architects' of globalisation. As I have argued, if we see power as shifting and circulating in webs or networks, the making of globalisation becomes more complex than the elite design of a global architecture. Sites of global restructuring become part of a web of social power relations that transcend and defy the boundaries of states, firms and organisations. An apparent project of labour flexibilisation is not controlled in a linear manner by holders of power, but is riven with contradictions and tensions. Groups that we may define as significant in shaping the restructuring of work - for example, policymakers, corporate managers and workers - do not always do so in predictable and instrumental ways. It will be clear from the chapters that follow that not all managers promote globalisation and flexibility, and nor do all workers resist. Indeed we can say that some worker relationships may, in fact, enable globalisation. People cannot easily be assigned to roles of 'promoting' or 'resisting' globalisation and, therefore, an analysis of their situations within webs of power relations is better equipped to reveal the ambiguous and cross-cutting nature of affiliation and dissent.

3 Social practice and the 'everyday' - I have argued that it is in the realm of everyday life that understandings, experiences, and meanings of globalisation and global restructuring are produced and reproduced. IPE inquiry has for too long assumed that the 'everyday' is a parochial realm, one which holds only secondary importance for inquiry. But what is the 'global economy', 'the market', 'the MNC', if it is separate from the experience and knowledge of living in a world we call global? IPE has tended to assume that we examine 'small scale' empirical details in order to explain the bigger picture. Drawing on conceptualisations of the everyday, I have suggested that it is in this realm that meaningful global social change takes place. From this standpoint, the 'restructuring of the state' or the 'strategy of the firm' becomes concrete when viewed through the everyday social practices that may constitute or contest it. Of course, past practice becomes institutionalised and constrains present and future actions, but these institutions are not prior to social relations. Work, conceived as everyday social practice, is one means through which representations and concrete realities of globalisation are enabled, contested or confounded. 
Notes

1 Strange (1984) emphasises the potential for 'openness' which is held out to the social sciences by IPE. This 'openness' constitutes both a willingness to consider the insights of a wide range of social groups, academics and practitioners, and an acceptance of the significance of a diverse range of subject matter, issues and concerns.

2 Strange's (1984) Paths to IPE represents a clear statement of the problematic of IPE inquiry. The chapters by Tooze and Strange mark out early divergences in the conception of the ontological and epistemological bases of the field.

3 The finance structure is defined as 'the sum of all the arrangements governing the availability of credit plus all the factors determining the terms on which currencies are exchanged for one another' (1988: 68). The security structure is the 'framework of power created by the provision of security by some human beings for others' (Strange, 1988: 44). The production structure is defined as 'the sum of all the arrangements determining what is produced, by whom and for whom, by what method and on what terms' (1988: 62). Finally, the knowledge structure 'comprehends what is believed ... what is known and perceived as understood; and the channels by which beliefs, ideas and knowledge are communicated - including some people and excluding others' (1988: 15). In each of the structures the emphasis is on 'who benefits' and who loses or is excluded from the arrangements.

4 See, for example, Hettne (1995), Gill (1995a; 1997), Bienefeld (1991), Birchfield (1999), Bernard (1997).

5 For discussions of the use of historical sociology in interdisciplinary and IPE inquiry, see Leander (2000), Skocpol (1984).

6 Hettne has it that Polanyi offers a 'historical' but not a 'historicist' route into IPE inquiry (1995: 5). The historical sociologists use of Polanyi similarly marshalls historical material, but does not 'historicise' this material. See, for example, Goldthorpe's analysis of what he terms 'grand historical sociology' (1996: 112). For Goldthorpe, the work of Skocpol and Hall, for example, engages with a debate about the use of history in sociology without actually employing a historical mode of thought. Hence, the historical sociologists rely upon comparative historical material on differences between societies, for example, but do not emphasise the role of interpretation in these cases.

7 See, for example Cox (1981; 1983; 1996), Gill (1990; 1993; 1995), Gill and Mittelman, (1997), Harrod, (1987; 1997a), Murphy (1994).

8 The concept of 'anti-globalisation strategies' has become common parlance in the new media. See, for example, Channel 4 (2001) 'Politics Isn't Working: The End Of Politics', 13 May.

9 Cox (1992b) describes the shift in the relationships of states to the world political economy in terms of a 'post-Westphalian' order.

10 Gill (1993) outlines a 'post-hegemonic' research agenda. Indeed, early IPE debates were rather dominated by the issues surrounding the possible demise of the Pax Americana and the shape of a future new world order (Gamble, 1995).

11 For Hettne: 'Judging from the current debate in IPE and IR theory, we live in a period of "transformation" or "transition". In historical studies of transition from one system to another, we have the record - that is, both the starting points and the end points are known to us. In studies of contemporary "transitions" or processes of transformation, we don't know the end points' (1995: 10).

12 I first raised these questions with others in the Newcastle IPE discussion group (Amoore 
et al., 2000). I thus owe many of these points to discussions and writing that took place within the group.

13 Cox (1996: 27) explicitly outlines the 'influences and commitments' of his work. Under the broad heading of historicism, Cox highlights the work of Georges Sorel, E. H. Carr, E. P. Thompson, R. G. Collingwood, Giambattista Vico, Benedetto Croce, Antonio Gramsci and Fernand Braudel.

14 Ronen Palan comments that Strange does not allude to the 'authors of structural power', Poulantzas, Foucault and Mann (1999: 128).

15 Foucault outlines transversal struggles as 'immediate' struggles that are not limited to one country (1982: 211). Campbell extends this to suggest that transversal struggles 'not only transverse all boundaries; they are about these boundaries' (1996: 23).

16 Latour's (1991) stories of the use of weights to encourage the return of hotel keys, and the development of the Kodak camera demonstrate the contingency and displacement of apparently 'designed' strategies. 